\title{
ASSET LIABILITY MANAGEMENT AND COMMERCIAL BANKS' PROFITABILITY IN NEPAL
}

\author{
Sanjay Shrestha
}

Department of Management, TU, Thakur Ram Multiple Campus, Birgunj, Nepal

\begin{abstract}
This study examines the effect of ALM on commercial banks' profitability in Nepal. ALM deals with the optimal investment of assets in view of meeting current goals and future liabilities. For this purpose top seven private commercial banks were taken as sample, which constitutes 49 percent share of total net profit of overall 30 commercial banks over 7 years time period from 2007-08 to 2013-14. The report emphasizes that the rate of return on assets is positive and varies across assets, and the rate of cost on liabilities is negative and varies across liabilities. The pooled OLS regression analysis result showed that all assets, including fixed assets, mainly loans and advances as well as other assets affect profitability positively, while all liabilities, mainly deposits, and other liabilities have negative effect on commercial banks profitability. With regard to macroeconomic variables, GDP and Inflation rate has negative effect on commercial banks profitability. As a result, the study recommended that commercial banks should focus on increasing public awareness to mobilize more saving and fixed deposits and this will enhance their performance in provision of loans and advance to customers.
\end{abstract}

\section{Key words}

\section{Introduction}

Commercial banks play an important role in the development of a country. A sound, progressive and dynamic banking system is a fundamental requirement for economic development. As an important segment of the tertiary sector of an economy, commercial banks act as the backbone of economic growth and prosperity by acting as a catalyst in the process of development. They inculcate the habit of saving and mobilize funds from numerous small households and business firms spread over a wide geographical area. The funds so mobilized are used for productive purposes in agriculture, industry and trade.

Given the relation between the well-being 
of the banking sector and the growth of the economy, knowledge of the underlying factors that influence the financial sector's profitability is therefore essential not only for the managers of the banks, but also for numerous stakeholders such as the central banks, bankers associations, governments, and other financial authorities. Knowledge of these factors would be useful in helping the regulatory authorities and bank managers formulate future policies aimed at improving the financial performance of the Nepalese banking sector.

There are many aspects of the profitability of commercial banks that can be analyzed. This study focuses on the Assets Liability Management (ALM) and commercial banks' profitability in Nepal. This study employed the correlation, regression and descriptive analysis to examine the effect of ALM on commercial banks of Nepal during the sample period of 2007-08 to 2013-14. This research report can be of particular interest to bank management, as the managers can employ this analysis to identify the relative position of their banks in relation to their main competitors. This enables them to identify their competitive advantages and disadvantages and to change their policies towards ALM. Besides, this research can make some sort of contribution to the literatures relating to banks ALM. Because the research is conducted in a country where the financial sector is dominated by commercial banks, the findings can be useful for developing countries under the same scenarios. Last but not least, it can be of paramount importance for policy makers to evaluate their policies, regulation, directives in line with the finding of the research.

\section{Concept of asset liability management}

Asset liability management, ALM, is defined by different scholars like Gup and Brooks (1993), Zawalinska (1999) and Charumathi (2008). Charumathi (2008) defines ALM as a dynamic process of planning, organizing, coordinating, and controlling the assets and liabilities; their mixes, volume, maturities, yield, and costs in order to achieve a specified net interest income (NII). In other words, it deals with the optimal investment of assets in view of meeting current goals and future liabilities. It is therefore appropriate for institutions (banks, finance companies, leasing companies, insurance companies, and others) to focus on asset-liability management when they face financial risks of different types. Asset liability management includes not only a formalization of this understanding, but also a way to quantify and manage these risks. Further, even in the absence of a formal asset liability management program, the understanding of these concepts is of value to an institution as it provides a truer picture of the risk/reward trade-off in which the institution is engaged (Fabozzi and Kanishi, 1991).

The concept of the ALM was developed as a hedging reaction against the risk of financial intermediation. As a discipline, ALM has been functioning since the beginning of 1970 . At the initial stage, the management was based on the simple gap model that analyzes risk in terms of cash flows and the gaps or mismatches between assets and liabilities. As the experiences of financial institutions with risk management evolved, the cash flow gap models gradually gave way to duration gap models, which look more at the market value of the bank's rate-sensitive assets and rate-sensitive liabilities (to changes in interest rates) rather than just at the difference between them. At present, the rapid development in the ALM field is driven by such forces like: recent growth in the capital markets, advancement in the theory and technology of risk analysis, education of financial intermediaries in the necessity as well as in implementation of ALM. Fabozzi \& Konishi (1998) identify three requirements for a successful implementation of ALM. A thorough understanding of the ALM concept is the first among these requirements. 
It refers to a comprehensive recognition of the banking risk. Besides serving as a venue for understanding the scope of risk, ALM allows for the quantifiable assessment and effective management of various risk categories. Even in the absence of a formal ALM program, the understanding of these concepts provides a picture of the risk/reward trade-off in which the financial institutions are engaged. The second step or requirement for the implementation of ALM is the development of an information system. The set of data alone is likely to provide valuable information about the degree of financial risk affecting the institution. The third step involves a design and implementation of the ALM decision making process. The Asset Liability Committee (ALCO) usually carries out this process. According to Memmel \& Scherteler (2010), traditional perception on such financial intermediaries show a simple logic that a bank accept deposits with short term maturities from a large number of individuals and grants loans with long term maturities to a small number of borrowers. These transformation activities expose a bank to credit, interest rate, and liquidity risks.

\section{Banks' profitability}

Aburime (2008) observed that the importance of banks' profitability can be appraised at the micro and macro levels of the economy. At the micro level, profit is the essential prerequisite of a competitive banking institution and the cheapest source of funds. It is not merely a result, but also a necessity for successful banking in a period of growing competition on financial markets. Hence the basic aim of every bank management is to maximize profit, as an essential requirement for conducting business. At the macro level, a sound and profitable banking sector is better able to withstand negative shocks and contribute to the stability of the financial system. Bank profits provide an important source of equity especially if reinvested into the business. This should lead to safe banks, and as such high profits could promote financial stability (Flamini et al.,
2009). However, too high profitability is not necessarily good. Uzhegova (2010) observed that too high profitability could be indicative of market power, especially by large banks. This may hamper financial intermediation because banks exercising strong market power may offer lower returns on deposit but charge high interest rates on loans. Too low profitability, in turn, might discourage private agents (depositors and shareholders) from conducting banking activities thus resulting in banks failing to attract enough capital to operate. Furthermore, this could imply that only poorly capitalized banks intermediate savings with the corresponding costs for sustainable economic growth.

\section{Effects of ALM on bank profitability}

The profitability of commercial banks is vital for the smooth operation of the financial system of a country (Tektas et al., 2005). In our country, even though the financial sector is regulated as all of other countries financial sector, it is contributing a lion share for the healthiness of the country's financial system. Therefore, the sector's profitability is of the major concern for those who are responsible for policy making and operating day to day with it. Among the possible factors that have effect on commercial banks profitability asset liability management (ALM) is the major one (Asiri, 2007).

In the banking area, different authors try to study the determinants of commercial banks profitability. Most recently, Ramlall (2009) and Alper \& Anbar (2011) found that bank profitability can be hindered by both internal and external factors. Internal factorsare related to bank management which encompasses the ALM culture of the bank and external determinants are factors which reflect the economic and legal environment that affect the operation and performance of commercial banks. The common macroeconomic factors that determine the profitability of banks in general and commercial banks in particular 
are GDP, inflation rate, market interest rates, and ownership.

With regard to the microeconomic determinants of commercial banks profitability, ALM plays a dynamic role. According to Hester \& Zoellner (1966), there is statistically significant relationship between ALM and profitability and they disregard the null hypothesis that there is no relationship between them. On the contrary, Kosmidou et al. (2004) found that liability management plays its own pivotal role in contributing profitability difference among commercial banks. However, before this study Vasiliou (1996) suggests that asset management rather than liability management play the key role in explaining the differences in banks profitability.

Practically, therearealsoother macroeconomic factors that have effect on commercial banks profitability. Although they have not found evidence that differential returns and costs on different categories of assets and liabilities exist, Kwast and Rose (1982) expanded the traditional SCA model to incorporate market structure and inflation rate as macroeconomic variables. Recently, Asiri (2007) found that assets management positively and liabilities management negatively related to the profitability of Kuwaiti banks. Similarly, Belete (2013) found that the profitability of commercial banks is positively affected by assets management, except for fixed assets and is negatively affected by liability management while real growth in GDP and the general rate of Inflation have negative effect on banks profitability.

\section{Methods}

Research design means an overall framework for the activities to be taken during the course of a research study. Firstly, it specifies the sources \& type of information relevant to research question, secondly it specifies; the data. Thus, a research design specifies various methods \& procedures for acquiring the information including from which sources \& by what procedure it is obtained.

In context of Nepal, 30 commercial banks are in operation. These thirty banks are regarded as population. But, it is not possible to study all data related with these all banks. Hence, for this study 7 commercial banks have been taken as sample from the whole population. They include NABIL Bank, Nepal Investment Bank, Everest Bank, Himalayan Bank, Global IME Bank, Nepal SBI Bank and Standard Chartered Bank.

The study employs secondary data. The annual reports of relevant banks are collected from the respective website, along with published Banking \& financial statistics of Nepal Rastra Bank from July 2014. Data are collected for the period from 2007-08 to 2013-14. The study covered a seven year period from the years Mid July 2007 to 2014.

The data collected is analyzed using the computer software known as Statistical Package for Service Solution (SPSS) version 16.o. Descriptive, correlations and regression analysis was applied to study and compare the effect of independent variables on the dependent variable. In order to get a picture of the profitability of the banks, ROA, which is a measure of Profitability, has been employed. ROA reflects the ability of a bank's management to generate profits from the bank's assets and was calculated as net profit after tax divided by Total assets.

ROA is the dependent variable while asset liability management components are the independent variables of the research study. Here, two tailed t-test is used since the sample size is greater than 30 with a $5 \%$ statistic test of significance. Computation of correlation coefficient $(\mathrm{r})$, coefficient of determination (r2) and analysis of variance (ANOVA) using the regression model below. The study hypothesis is that asset liability management has a positive relationship to Commercial Banks' Profitability. 
$\mathrm{ROA}=\alpha+\mathrm{L}_{1} \mathrm{X}_{1}+\mathrm{L}_{2} \mathrm{X}_{2}+\mathrm{A}_{1} \mathrm{X}_{3}+\mathrm{A}_{2} \mathrm{X}_{4}+\mathrm{A}_{3}$ $\mathrm{X}_{5}+\mathrm{GDP} \mathrm{X}_{6+} \mathrm{INF} \mathrm{X}_{7}+\mathrm{C}$

Where;

Ydenotes the dependentvariable (Commercial Bank's Profitability) measured as Return on Assets

$\alpha$ is the value of the intercept.

$\beta$ is the coefficient of the explanatory $\mathrm{X}$ variable.

$\mathrm{e}$ is the error term assumed to have zero mean and independent across time period.

$\begin{array}{ll}\text { L1 } & \text { Deposit } \\ \text { L2 } & \text { Other Liabilities } \\ \text { A1 } & \text { Loans, Advances and Bills }\end{array}$

Purchase

$\mathrm{A} 2$

Fixed Assets

A3

Other Assets

GDP

Product

Nominal Gross Domestic

INF

Rate of Inflation

\section{Results and discussion}

The descriptive statistics of the explanatory and explained variables in this study are presented in Table 1. It is based on a panel data set organized from seven commercial banks operating in the Nepalese financial market during the period from 2007 to 2014. Looking at them, generally, the statistics indicate a wide variability exist in both the balance sheet and macroeconomic variables which have effect on commercial banks profitability. The ROA has a mean value of $1.82 \%$ with standard deviation of $0.663 \%$. The mean value of the Loans, Advances and Bill Purchase variable $\left(\mathrm{A}_{1}\right)$ is Rs. 28.8 Billion. Fixed Assets (A2) variable has the mean value of Rs. 0.742 Billion. Other Assets variable $\left(\mathrm{A}_{3}\right)$ has a mean of Rs. 18.4 Billion which may portrays above half of commercial banks assets are in the form of loans, advances and Bills Purchase. It has standard deviation of Rs. 12.32 Billion which also show there was greater variability than all other asset variables used in the study. The low mean value of Fixed Assets variable (A2) might imply that funds used in acquisition of fixed assets has minimum portion than other asset items.

The first liability variable, which is the deposits (L1), has mean value of Rs. 42 Billion with standard deviation of Rs. 15.65 Billion. Other liabilities variable (L2) has mean value of Rs. 2.11 Billion. The mean value of deposits variable is higher which probably show that it is the major source of funds for commercial banks. It is because commercial banks are financial intermediaries which have a simple logic that accept deposits with short term maturities from a large number of individuals and grant loans with long term maturities to a small number of borrowers.

The macroeconomic variables incorporated in this study have the mean value of 16.88 and $9.38 \%$ with the standard deviation of 2.89 and $1.678 \%$ for nominal GDP and the general rate of inflation, respectively. The comparison between minimum and maximum values with the mean value of real growth rate in GDP shows there is lower variability in the variable. Nevertheless, there is greater variability in the general rate of inflation which has big standard deviation in relation to real growth rate in GDP variable. Generally, from the source of funds variables, deposits variable has significant proportion. While from the use of funds variables, loans and advances variable has higher mean value and proportion. These imply that most of the commercial banks operating in Nepal during the study period are financed through deposits and they have used the fund for provision of loans and advances.

In relation to standard deviations, fixed assets and other liabilities have lower variability, while loans and advances and deposits have greater variability, from the use and source of funds point of view, respectively. 
Table 1: Aggregate mean scores of ALM factors between 2007 and 2014

\begin{tabular}{|c|c|c|c|c|c|}
\hline & $\mathbf{N}$ & Minimum & Maximum & Mean & $\begin{array}{c}\text { Std. } \\
\text { Deviation }\end{array}$ \\
\hline ROA & 49 & o & 3 & 1.82 & .663 \\
\hline L1 & 49 & 7319702 & 8.E7 & $4.20 E_{7}$ & $1.565 \mathrm{E}_{7}$ \\
\hline $\mathrm{L} 2$ & 49 & 223393 & 7232935 & $2.11 \mathrm{E} 6$ & 1165211.740 \\
\hline$A_{1}$ & 49 & 5084729 & & $2.88 \mathrm{E}_{7}$ & $1.232 \mathrm{E}_{7}$ \\
\hline $\mathrm{A}_{2}$ & 49 & 68725 & 6315947 & $7.42 \mathrm{E}_{5}$ & 893095.546 \\
\hline $\mathrm{A}_{3}$ & 49 & 3075602 & 4.E7 & $1.84 \mathrm{E}_{7}$ & 7912955.453 \\
\hline GDP & 49 & 13 & 20 & 16.88 & 2.890 \\
\hline INF & 49 & 7 & & 9.38 & 1.678 \\
\hline Valid N (list wise) & 49 & & & & \\
\hline
\end{tabular}

Correlation analysis of ALM and commercial banks' profitability

Table 2 shows the correlations between asset liability management factors and profitability of commercial banks, while holding the correlation coefficient $(\mathrm{r})$ value at between plus and minus one $(-1.00$ and +1.0$)$. The study used the significance level of alpha $=.05(95 \%)$, degree of freedom (df) of 7 and two-tailed test. The study shows that ROA is positively correlated with all the liability variables including
Deposit and Other liabilities \& all the assets variables, except fixed assets. In other words, $\mathrm{ROA}$ is positively correlated with loans \& advances and other assets but negatively correlated with fixed assets. In case of macroeconomic variables, there is positive correlation between ROA and GDP while Inflation has negative correlation with ROA. This indicates in case of Inflation, profitability of commercial bank is adversely affected.

Table 2: Correlation on ALM factors

\begin{tabular}{|l|c|c|c|c|c|c|c|c|}
\hline $\begin{array}{c}\text { Pearson Corela- } \\
\text { tion }\end{array}$ & ROA & $\begin{array}{c}\text { Depos- } \\
\text { it }\end{array}$ & $\begin{array}{c}\text { Ot h er } \\
\text { Liabili- } \\
\text { ties }\end{array}$ & $\begin{array}{c}\text { Loan s } \\
\text { \& Ad- } \\
\text { vances }\end{array}$ & $\begin{array}{c}\text { F i e d } \\
\text { Assets }\end{array}$ & $\begin{array}{l}\text { Ot h e r } \\
\text { Assets }\end{array}$ & GDP & INF \\
\hline ROA & 1.0000 & & & & & & & \\
\hline Deposit & 0.4666 & 1.0000 & & & & & & \\
\hline Other Liabilities & 0.5267 & 0.7497 & 1.0000 & & & & & \\
\hline Loans \& Advances & 0.4149 & 0.9238 & 0.7902 & 1.0000 & & & & \\
\hline Fixed Assets & -0.0333 & 0.3436 & 0.2751 & 0.4364 & 1.0000 & & & \\
\hline Other Assets & 0.4766 & 0.8094 & 0.5348 & 0.5327 & 0.0022 & 1.0000 & & \\
\hline GDP & 0.1909 & 0.6474 & 0.3602 & 0.5975 & 0.2209 & 0.5248 & 1.0000 & \\
\hline INF & -0.0224 & 0.0436 & 0.0142 & 0.0273 & 0.0438 & 0.0407 & -0.0879 & 1.0000 \\
\hline
\end{tabular}


Table 3: Coefficient and t-statistic

\begin{tabular}{|c|c|c|c|c|c|c|}
\hline & \multirow{2}{*}{$\begin{array}{l}\text { Model } \\
\text { B }\end{array}$} & \multicolumn{2}{|c|}{$\begin{array}{c}\text { Unstandardized } \\
\text { Coefficients }\end{array}$} & $\begin{array}{c}\text { Standardized } \\
\text { Coefficients }\end{array}$ & \multirow[t]{2}{*}{$\mathbf{t}$} & \multirow[t]{2}{*}{ Sig. } \\
\hline & & Std. Error & Beta & & & \\
\hline \multirow[t]{8}{*}{1} & (Constant) & 2.083 & .702 & & 2.967 & .005 \\
\hline & $\mathrm{L} 1$ & $-4 \cdot 313 E-7$ & .000 & -10.176 & -2.960 & .005 \\
\hline & $\mathrm{L}_{2}$ & $-2.982 \mathrm{E}-7$ & .000 & -.524 & -1.445 & .156 \\
\hline & A 1 & $4.031 \mathrm{E}-7$ & .000 & 7.490 & 2.994 & .005 \\
\hline & A2 & $2.944 \mathrm{E}-7$ & .000 & .396 & 1.732 & .091 \\
\hline & $A_{3}$ & $4 \cdot 331 \mathrm{E}-7$ & .000 & 5.168 & 3.122 & .003 \\
\hline & GDP & -.071 & .039 & -.310 & -1.836 & .074 \\
\hline & INF & -.012 & .045 & -.031 & -.274 & .786 \\
\hline
\end{tabular}

a. Dependent Variable: ROA

\section{Regression of asset liability management and financial performance}

The $\mathrm{R}^{2}$ is a measure of the goodness of fit of the asset liability management factors variables in explaining the variations in banks' profitability. Based on the study, correlation coefficient (r) was .689 and the coefficient of determination (r2) was .475 indicating that $47.5 \%$ of the commercial banks' profitability can be predicted by the ALM and macroeconomic variables identified in the study. Since the correlation of .475 is positive it can be concluded that the correlation is statistically significant, hence there is a positive relationship between asset liability management and commercial banks' profitability.

The findings of the analysis are based on the significance level (alpha) of 0.05, degrees of freedom (df) of 7 , and two-tailed test as Table 3 indicates. The result show a positive coefficient of determination ( $\mathrm{R} 2$ ) indicating that: return on assets is influenced by Deposits (L1), Other liabilities (L2), Loans \& Advances (A1), Fixed Assets (A2), Other Assets(A3), GDP and Inflation capital . In addition, the computed t-values: Deposits (L1) $(\mathrm{t}=-\mathbf{2 . 9 6 7 1})$; Loans \& Advances (A1) ( $\mathrm{t}=2.944)$; Other Assets $\left(\mathrm{A}_{3}\right)(\mathrm{t}=3.122)$; are higher than the significance threshold of 1.96 (o.05). This then indicate that there is a significant relationship between Commercial Banks' Profitability and Deposits, Loans \& Advances and Other Assets.

The results indicate that deposits are negatively related to return on assets (ROA), the financial performance measure. The coefficient of determination is -4.313 which indicates that the strong negative relationship between them. These results provide reasonable evidence to the consistent view that, the higher the deposit levels will cost on profitability. The negative coefficients mean a Rs. 1000 increase in deposit leads to a $4.313 \%$ decrease in profitability on average other things remaining constant. Similarly, coefficient of determination of other liabilities is $-\mathbf{2 . 9 8 2}$ which also shows negative relation to return on assets (ROA). Likewise coefficient of determination of Loans \& Advance, Fixed Assets and Other Assets are 4.031, 2.944 and 4.331 respectively which shows positive relation to (ROA). However, macroeconomic variables: GDP and Inflation have negative coefficient of determination of -0.071 and -o.o12 which specifies their negative relation with profitability of commercial banks.

\section{Conclusion}

The analysis has shown that all the ALM had a statistically significant impact on financial performance. The descriptive analysis shows 
that deposits on liability part and loans $\&$ advances on the asset part have major contribution in the generation of profitability to the commercial banks.

The correlation analysis has shown that ROA is positively correlated with all the liability variables including Deposit and Other liabilities \& all the assets variables, except fixed assets. In relation to macroeconomic variables, ROA is positively correlated with GDP while negatively correlated with rate of Inflation.

Multiple regression analysis has shown that asset liability management is not only related to the profitability of banks, but they also influence the financial performance of commercial banks in Nepal significantly with a correlation of 0.475 . The analysis assets and liability variables are the most robust and important factor influencing profitability financial performance in the sector.

From this study, it can be concluded that assets have positive impact on commercial banks' profitability. Liabilities have negative impact on commercial banks' profitability. In the context of macroeconomic variable, Both GDP and Inflation have negative influence of commercial banks' profitability but they have broader aspect in the economic development of Nepal.

On the basis of the findings of the study it is recommended that superior financial performance of commercial banks in terms of Profitability can be achieved by improving their Assets and Liability Management. The major focus should be to mobilize deposits and advancing loans with the portfolio management of balance sheet variables for risk diversification in order to generate higher profitability. Likewise, in developing country like Nepal focus should also be given in formulating policies to incorporate macroeconomic variables like GDP, Inflation Rate and others to avoid adverse effects on the profit generation.

\section{References}

Alper, D. \& Anbar, A. (2011). Bank specific and macroeconomic determinants of commercial bank profitability: Empirical evidence from Turkey. Business and Economics Research Journal, 2 (2), 139-152.

Asiri, B. K. (2007). Assets-liabilities management in bank - a case of Kuwait. Indian Journal of Economics and Business, 6 (1), 103-115.

Belete, T. (2013). Assets liability management and commercial banks' profitability in Ethiopia, Research Journal of Financial Accounting, 4 (10)....

Charumathi, B. (2008). Assets liability management in Indian banking industry - with special reference to interest rate risk management in ICICI bank, World Congress on Engineering, July 2 -4, London, UK,.

Fabozzi, F. J., \& Konishi, A. (1995). Asset - liability management. New Delhi: S Chand \& Co.

Flamini, C., Valentina, C., McDonald, G. \& Liliana, S. (2009). The determinants of commercial bank profitability in Sub-Saharan Africa. IMF working paper.

Gup, B. E., \& Brooks, R. (1993). Interest rate risk management. Burr Ridge: Irwin Professional Publishing.

Hester, D. D., \& Zoellner, J. F. (1966). The relation between bank portfolios and earnings: an econometric analysis, Review of Economics and Statistics, 48, 372-386. 